\section{Commentary: Repair of complete atrioventricular septal defect: The bar has been set}

\section{David M. Overman, MD}

Johanssen Ramgren and colleagues ${ }^{1}$ report outcomes in a consecutive series of patients with balanced complete atrioventricular septal defect (cAVSD) spanning 25 years is remarkable for a few reasons. It also points to structural attributes that are intrinsic to optimization of care in a national context.

First, the authors report an operative mortality rate (as defined by the databases of North America and Europe ${ }^{2,3}$ ) of $1.6 \%$. That is the lowest operative mortality rate for cAVSD repair ever reported in a series of notable size. Second, overall freedom from reintervention on the left atrioventricular valve is $93.8 \%$ at 10 years-another recordsetting statistic. Third, younger age at repair $(<3$ months vs $>3$ months) was not a risk factor for either mortality or reintervention.

These clinical outcomes set a new standard for what is achievable after repair of balanced cAVSD. They present a strong argument that nonelective complete repair is the treatment of choice for patients failing medical management of congestive heart failure, even if they are very young. And they make a convincing argument that clinical algorithms utilizing pulmonary artery banding (PAB) for patients younger than standard elective repair age should be retired.

Of course, there are rare clinical scenarios in which control of pulmonary blood flow (and concomitant improvement of systemic output) without the use of cardiopulmonary bypass is desirable. The authors, in fact, utilized this strategy in a neonate with necrotizing enterocolitis. Such targeted use of PAB is still an important part of

\footnotetext{
From the Division of Cardiovascular Surgery, Children's Minnesota, Mayo ClinicChildren's Minnesota Cardiovascular Collaborative, and Division of Cardiac Surgery, The Children's Heart Clinic, Minneapolis, Minn.

Disclosures: The author reported no conflicts of interest.

The Journal policy requires editors and reviewers to disclose conflicts of interest and to decline handling or reviewing manuscripts for which they may have a conflict of interest. The editors and reviewers of this article have no conflicts of interest.

Received for publication Oct 2, 2020; revisions received Oct 2, 2020; accepted for publication Oct 5, 2020; available ahead of print Oct 10, 2020.

Address for reprints: David M. Overman, MD, The Children's Heart Clinic, 2530 Chicago Ave, S, Suite 500, Minneapolis, MN 55404 (E-mail: doverman@ @ chc-pa.org). J Thorac Cardiovasc Surg 2021;161:2154-5 $0022-5223 / \$ 36.00$

Copyright $(9) 2020$ Published by Elsevier Inc. on behalf of The American Association for Thoracic Surgery

https://doi.org/10.1016/j.jtcvs.2020.10.008
}

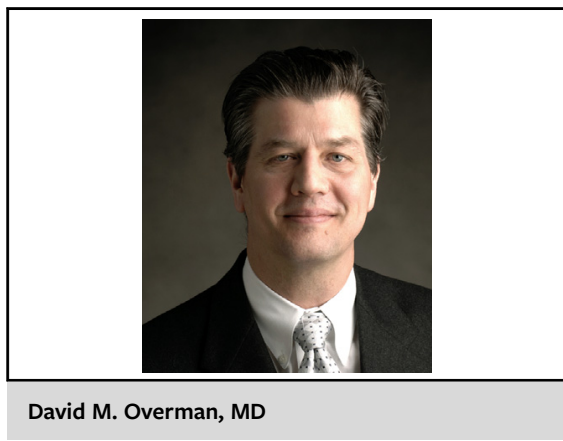

\author{
CENTRAL MESSAGE \\ Outstanding outcomes after \\ repair of complete AVSD are \\ achievable, suggesting that com- \\ plete repair should, with rare \\ exception, be offered to young \\ infants whose clinical status \\ warrant the procedure.
}

the surgical armamentarium. It is also worth noting that younger age is not a limitless concept. The younger group was composed of only 55 patients with a mean age older than 6 weeks; only 3 patients were neonates. Thus, inferences regarding complete repair in neonatal populations cannot be drawn from these data.

Nevertheless, the message is clear: extremely high survival and extremely low reintervention rates are achievable after cAVSD repair. How was this possible? The authors mention 3 important structural attributes:

1. A uniform clinical approach. The authors agreed on and practiced a standard policy over a 25 -year period. This minimizes hazards and optimizes management by homogenizing the treatment milieu. In the absence of consistent policy, chaos reigns and improvement is illusive.

2. Programmatic stability. Eight surgeons performed these operations, but only 2 performed the majority of the younger group's operations. These operations are composed of hundreds of little details, all requiring a judgment followed by an action. Longitudinal stability, with its retention of clinical knowledge and judgment, is vital to optimizing outcomes.

3. Volume. Had Sweden not undertaken regionalization of centers in 1992, this cohort would have been half this size, and the surgical staff would have spread out across 
twice as many centers. There can be little doubt that reducing Sweden's complement of cardiac centers to 2 had a major influence on the ability of this unit to produce these superlative outcomes.

This report documents how to clear a newly set bar. A consistently applied policy of early complete repair, with rare utilization of PAB, by a stable and experienced surgical staff with concentrated areas of expertise at a high volume regionalized cardiac center, produced heretofore unachieved clinical outcomes. We should all take heed.

\section{References}

1. Johansson Ramgren J, Nozohoor S, Zindovic I, Gustafsson R, Hakacova N, et al Long-term outcome after early repair of complete atrioventricular septal defect in young infants. J Thorac Cardiovasc Surg. 2021;161:2145-53.

2. Jacobs JP, Mavroudis C, Jacobs ML, Maruszewski B, Tchervenkov CI, LacourGayet FG, et al. What is operative mortality? Defining death in a surgical registry database: a report of the STS congenital database taskforce and the joint EACTS-STS congenital database committee. Ann Thorac Surg. 2006;81: 1937-41.

3. Overman DM, Jacobs JP, Prager RL, Wright CD, Clarke DR, Pasquali SK, et al. Report from the Society of Thoracic Surgeons national database workforce: clarifying the definition of operative mortality. World J Pediatr Congenit Heart Surg. $2013 ; 4: 10-2$
See Article page 2145 .

\section{Commentary: Complete atrioventricular septal defect in young infants: The advantages of early repair}

\author{
Harold M. Burkhart, MD, ${ }^{\mathrm{a}}$ and \\ Heather N. Anderson, MD
}

The current approach of elective primary repair of complete atrioventricular septal defect (cAVSD) at 3 to 6 months of age appears to be a widely supported standard of care in the congenital surgical world. Sturdier valvular tissue, improved intracardiac visualization, and time for patients with a borderline left ventricle to show appropriate ventricular growth are just a few of the benefits associated with this approach. Controversy exists as to the best approach to the symptomatic neonate or young infant. Much is written supporting a staged tactic using a main pulmonary artery band (PAB) to control heart failure symptoms followed by complete repair with $\mathrm{PAB}$ removal at an older age. ${ }^{1,2}$ However, there exists

\footnotetext{
From the ${ }^{\mathrm{a}}$ Division of Cardiovascular and Thoracic Surgery, and ${ }^{\mathrm{b}}$ Section of Pediatric Cardiology, University of Oklahoma Health Sciences Center, Oklahoma City, Okla.

Disclosures: The authors reported no conflicts of interest.

The Journal policy requires editors and reviewers to disclose conflicts of interest and to decline handling or reviewing manuscripts for which they may have a conflict of interest. The editors and reviewers of this article have no conflicts of interest.

Received for publication Sept 21, 2020; revisions received Sept 21, 2020; accepted for publication Sept 23, 2020; available ahead of print Sept 28, 2020.

Address for reprints: Harold M. Burkhart, MD, Division of Cardiovascular and Thoracic Surgery, University of Oklahoma Health Sciences Center, P.O. Box 26901, WP-2230, Oklahoma City, OK 73105 (E-mail: Harold-burkhart@ouhsc. edu).

J Thorac Cardiovasc Surg 2021;161:2155-6 $0022-5223 / \$ 36.00$

Copyright (c) 2020 Published by Elsevier Inc. on behalf of The American Association for Thoracic Surgery

https://doi.org/10.1016/j.jtcvs.2020.09.091
}

\section{Check for updates}

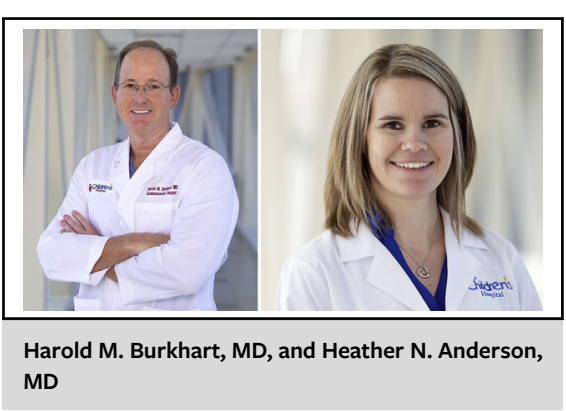

CENTRAL MESSAGE

Primary repair of complete atrioventricular septal defect in symptomatic young infants appears to be a viable approach.

literature advocating for early complete cAVSD repair in young infants, citing concerns for worsening common atrioventricular valve regurgitation and inter-stage demise.,

In this issue of the Journal, Ramgren and colleagues ${ }^{5}$ present their 25-year experience with more than 300 patients with cAVSD undergoing primary repair. They note that their institutional management is primary repair and avoidance of PAB staging, even in the younger infants. They compared several outcomes for patients following repair of cAVSD at the elective standard age (3-6 months, $\mathrm{n}=249)$ versus an early age ( $<3$ months, $\mathrm{n}=55)$ when there were indications for early intervention, such as severe atrioventricular $(\mathrm{AV})$ valve regurgitation or congestive heart 